\title{
Blowout mechanism of Alasehir (Turkey) geothermal field and its effects on groundwater chemistry
}

\author{
Rita Sandrina Rabet ${ }^{1} \cdot$ Celalettin Simsek $^{2} \cdot$ Alper Baba $^{3} \cdot$ Alim Murathan $^{4}$
}

Received: 25 July 2016/Accepted: 15 December 2016/Published online: 31 December 2016

(C) Springer-Verlag Berlin Heidelberg 2016

\begin{abstract}
Anatolia region is one of the most seismically active regions in the world and has a considerably high level of geothermal energy potential. Some of these geothermal resources have been used for power generation and direct heating. Most of the high enthalpy geothermal systems are located in western part of Turkey. Alasehir is the most important geothermal site in western part of Turkey. Many geothermal wells have been drilled in Alasehir Plain to produce the geothermal fluid from the deep reservoir in the last 10 years. A blowout accident happened during a geothermal well drilling operation in Alasehir Plain, and significant amount of geothermal fluid surfaced out along the fault zone in three locations. When drilling string entered the reservoir rock about $1000 \mathrm{~m}$, blowout occurred. As the well head preventer system was closed because of the blowout, high-pressure fluid surfaced out along the fault zone cutting the Neogene formation. In order to understand the geothermal fluid effects on groundwater chemistry, physical and chemical compositions of local cold groundwater were monitored from May 2012 to September 2014 in the study area. The geothermal fluid was found to be of $\mathrm{Na}-\mathrm{HCO}_{3}$ water type, and especially, arsenic and boron concentrations reached levels as
\end{abstract}

Celalettin Simsek

celalettin@deu.edu.tr

1 The Graduate School of Applied Science, Dokuz Eylul University, Izmir, Turkey

2 Department of Drilling, Torbali Technical Vocational School of Higher Education, Dokuz Eylul University, 35860 Torbali, Izmir, Turkey

3 Department of Civil Engineering, Izmir Institute of Technology, Izmir, Turkey

4 General Directorate of State Hydraulic Works, Izmir, Turkey high as 3 and $127 \mathrm{mg} / \mathrm{L}$, respectively. The concentrations of arsenic and boron in the geothermal fluid and groundwater exceeded the maximum allowable limits given in the national and international standards for drinking water quality. According to temporally monitored results, geothermal fluid has extremely high mineral content which influenced the quality of groundwater resources of the area where water resource is commonly used for agricultural irrigation.

Keywords Arsenic · Boron - Geothermal application · Groundwater · Turkey

\section{Introduction}

Turkey is located within the Mediterranean Earthquake Belt, in which complex deformation results from the continental collision between the African and Eurasian plates (Bozkurt 2001). The border of these plates constitutes seismic belts marked by young volcanic and active faults, while the latter allowing circulation of the geothermal fluid. The distribution of geothermal springs in Turkey roughly parallels the distribution of the fault systems, young volcanism and hydrothermally altered areas (Simsek 1997; Baba and Sözbilir 2012). There are about 1500 thermal and mineral water springs in Turkey (MTA 1980; Simsek 2009) (Fig. 1). The Geothermal Law (Geothermal Resources and Natural Mineral Water Act, No. 5686) was released on June 13, 2007, and designed in accordance with the Turkish Trade Law. After this law, many energy companies started to search for new geothermal sites in Turkey (Baba 2012). Nowadays, $2886 \mathrm{MW}_{\text {th }}$ is actually being utilized for direct applications and $650 \mathrm{MW}_{\mathrm{e}}$ of electricity is being generated. Many sites are now 


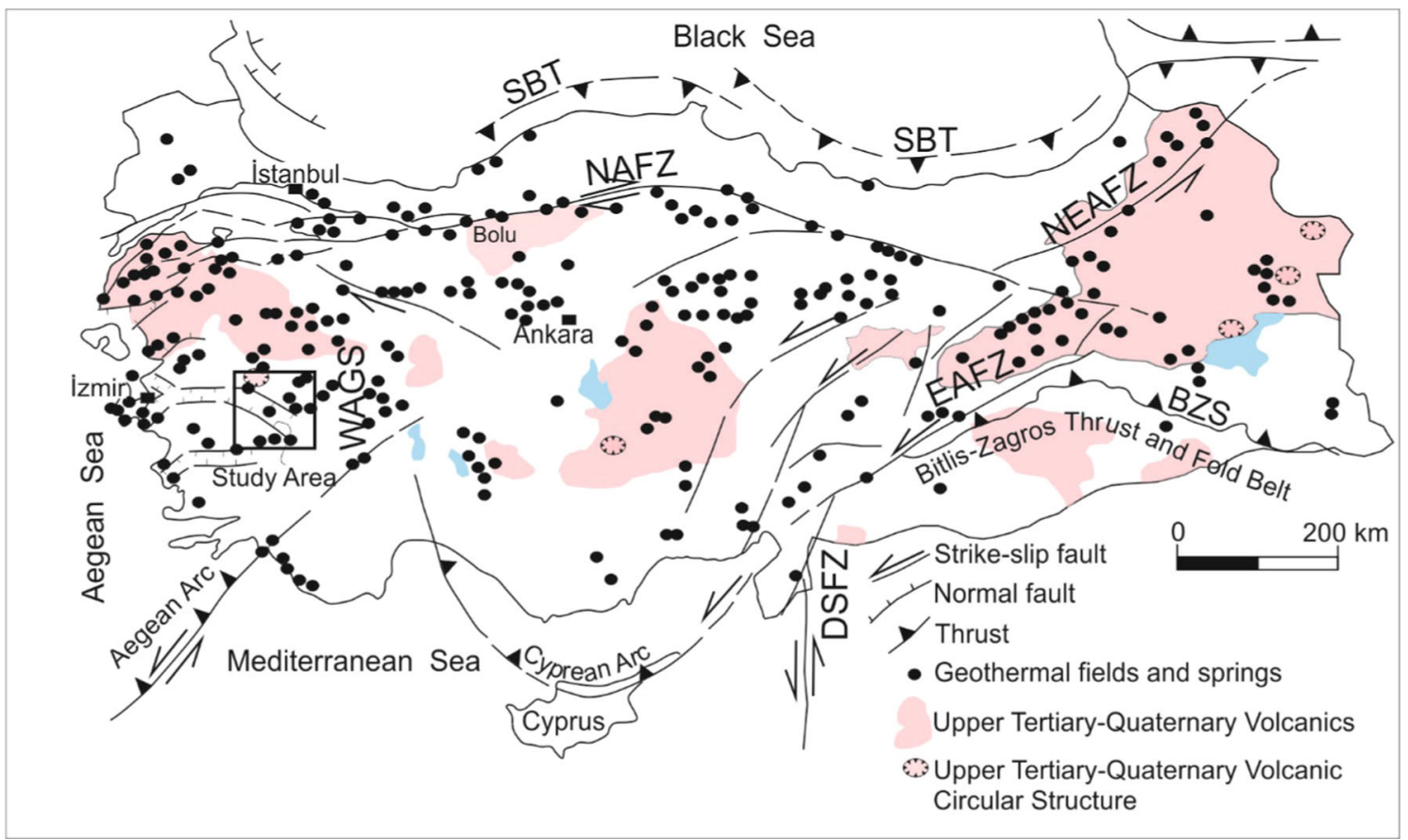

Fig. 1 Tectonic map of the eastern Mediterranean region showing structures developed during the Miocene to Holocene time and distribution of geothermal areas around Turkey (compiled from Simsek et al. 2002; Yigitbas et al. 2004). SBT Southern Black Sea

experiencing problems associated with uncontrolled drilling operations with developing geothermal energy applications such as electricity generation, green house and district heating, industrial processes, thermal tourism and balneology in different parts of Turkey (Baba and Murathan 2012). Geothermal energy is generally accepted as environmentally benign energy source. However, some uncontrolled geothermal applications have shown that they are not completely free of environmental impacts. Generally, it is known that geothermal utilization can cause surface disturbances, physical effects due to the fluid discharge, thermal effects on environment and emission of chemicals (Axtmann 1975; Baba and Ármannsson 2006). However, most of the scientific resources showed that this geothermal application can cause groundwater pollution (Demirel and Yildirim 2002; Dogdu and Bayari 2005; Aksoy et al. 2009).

With increasing popularity of geothermal energy in Turkey, some important graben areas became popular sites. Gediz Graben is situated in west of Turkey, and it is one of the most active exploration plains (Fig. 2). Within Gediz Graben, Alasehir Plain is a significant geothermal site and more than hundred geothermal wells were drilled to produce geothermal fluid in this region (Rabet 2015; Simsek 2016). The temperature of geothermal wells in Alasehir Plain ranges from 48 to $287{ }^{\circ} \mathrm{C}$. Many of the geothermal wells were drilled in Menderes metamorphic rocks, and
Thrust, NAFZ North Anatolian Fault Zone, NEAFZ Northeast Anatolian Fault Zone, EAFZ Eastern Anatolian Fault Zone, WAGS Western Anatolian Graben System, DSF Dead Sea Fault Zone, BZS Bitlis-Zagros Suture (Baba and Ármannsson 2006)

some wells had dramatic problems related to the geothermal fluid out flow. In particular, one of deep geothermal wells blowout during drilling and this geothermal fluid out cropped from three locations and along the fault zone affecting about 200 ha agriculture area. This well accident became the biggest phenomena in the region. The geothermal fluid originating from blowout fluid has flowed on the surface and within the subsurface since the blowout time. There are very few studies related to geothermal fluid intrusion in shallow alluvial aquifer. Therefore, this study focused on geothermal fluid and its effect on groundwater resources in Alasehir geothermal site in Gediz Graben.

\section{Study area}

\section{General characteristics}

The study area is located on Gediz Graben that is controlled by two major normal fault systems. The Alasehir Plain is located at the southeast of the Gediz Graben, and the majority of the plain is an important grape production area in Turkey (Fig. 2). The irrigation waters of these agricultural areas are mostly provided from the shallow alluvial aquifer that is formed as a result of the alluvial deposits of Alasehir Stream (Fig. 2). According to the local meteorological data, the watershed receives an average 


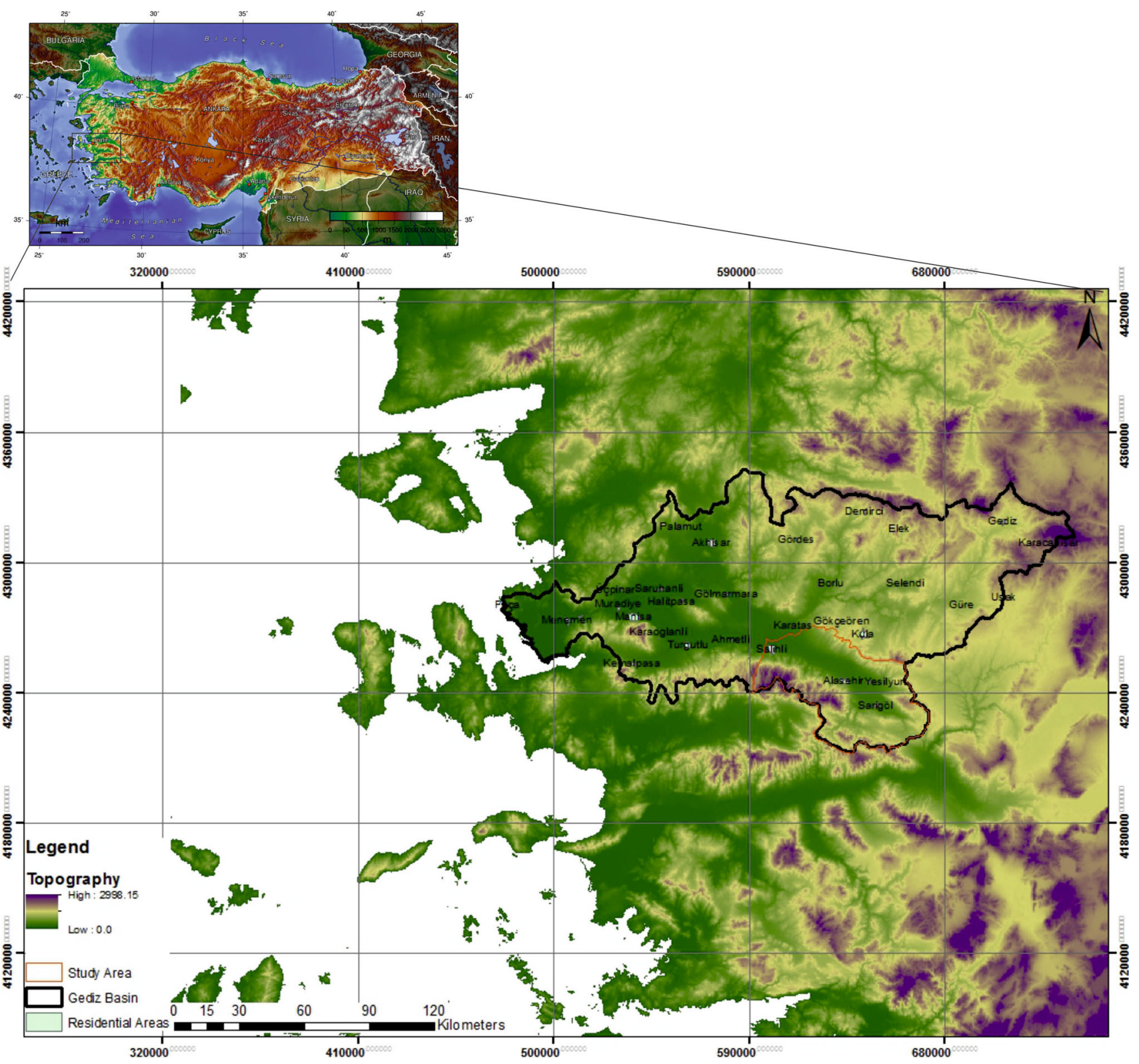

Fig. 2 Location map of the study area

annual total precipitation $439 \mathrm{~mm}$ with the highest monthly average (249 mm) occurring in January. Average maximum and minimum temperature values are specified as $28{ }^{\circ} \mathrm{C}$ (July) and $6.1{ }^{\circ} \mathrm{C}$ (January), respectively. These data show that the climate of the study area is characterized by typical Mediterranean climate with hot/dry summers and warm/rainy winters.

\section{Geological and hydrogeological characteristics}

The Gediz Graben is $140 \mathrm{~km}$ long and 3-40 km wide and has a WNW-ESE trending structure bounded by active normal faults. The Gediz detachment, which is located along a discontinuous trace along the fault for more than $100 \mathrm{~km}$ from Turgutlu to Alasehir district, is one of several crustal-scale detachment faults that were formed at the edge of the southern basin of the Gediz Graben (Kocyigit et al. 1999; Sözbilir 2002; Bozkurt 2003; Baba and Sözbilir 2012). The basement of the Gediz detachment composed of gneiss, schist and marble of the Menderes metamorphic core complex. The hanging wall of the detachment fault comprises Miocene to Quaternary sedimentary units reaching up to $2500 \mathrm{~m}$ thickness (Baba and Sözbilir 2012). Paleozoic-aged Menderes metamorphic is the basement rock in the study area (Fig. 3). The Alasehir Plain is filled with Neogene sedimentary rocks that lie with unconformity 


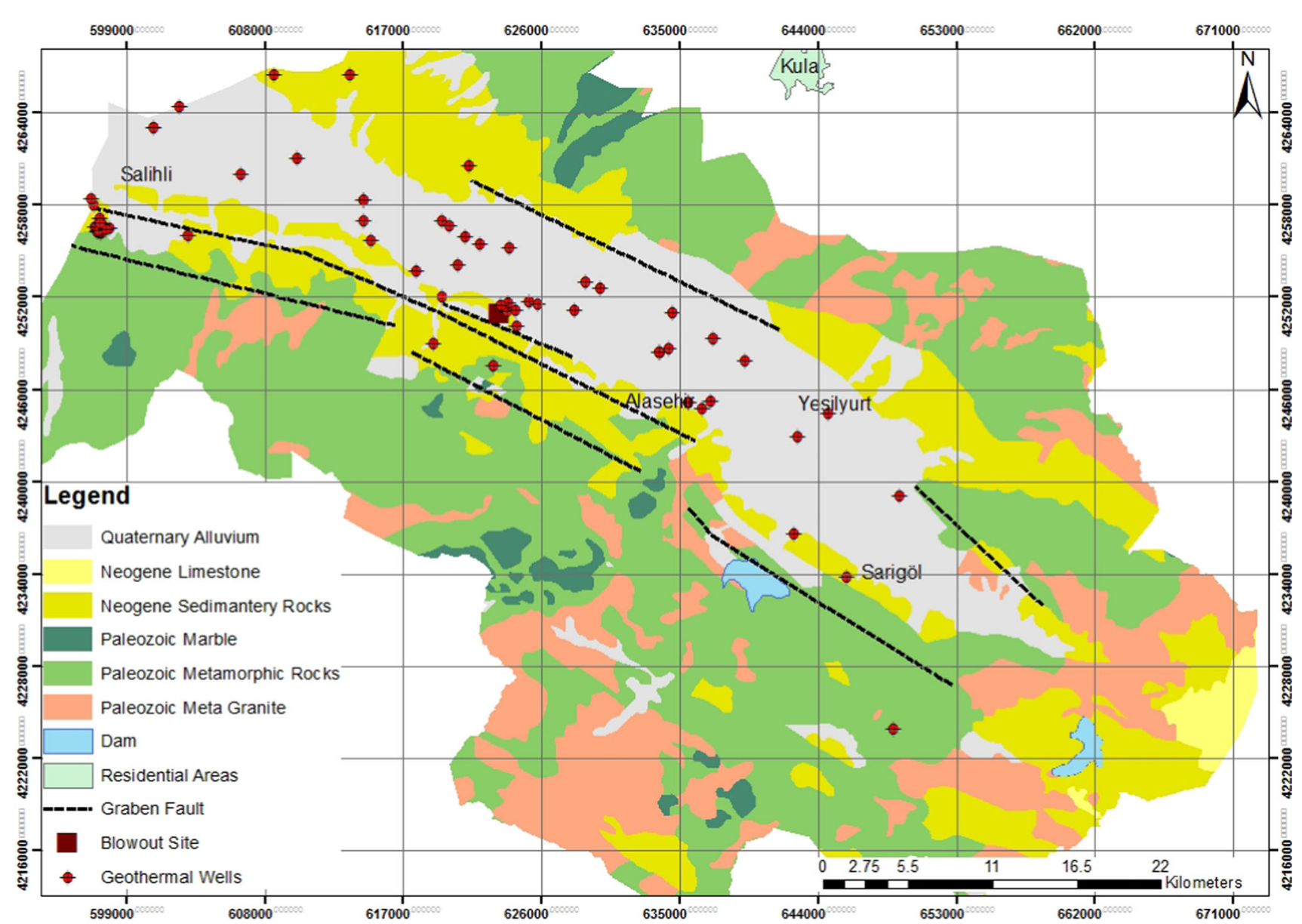

Fig. 3 Geological map of the Alasehir Plain (Geology map taken from DSI 2014)

over the Menderes metamorphic rocks. These series are composed of sandstone, conglomerate, claystone and limestone as well as volcanic layers (Seyidoglu et al. 2002). Finally, the Quaternary-aged unconsolidated sediments cover these units with unconformity throughout the plain (Fig. 3). This alluvial material mostly consists of clayey sands with gravel and thickness of these unconsolidated sediments reached up to $250 \mathrm{~m}$.

The marbles of the Menderes metamorphic rocks are highly fractured and considered as to be geothermal reservoir rock depending on the location and depth. The Neogene sediments are made up of sedimentary layers including sandy clayey levels with low permeability layer. In particular, claystone levels of the Neogene sediments are very thick impermeable layers for geothermal system. Alluvial layer is the most important and favorable aquifer for the groundwater production. Groundwater is supplied from this aquifer via deep wells which have depths ranging from 120 to $150 \mathrm{~m}$. The discharge rate of groundwater produced in these wells ranges from 5.0 to $30 \mathrm{~L} / \mathrm{s}$ (Ozen et al. 2010; Baba et al. 2016). The general groundwater flow direction in the alluvial aquifer system is from west to east in the study area. It is considered that the flow direction of blowout geothermal fluid is parallel to groundwater flow direction. The groundwater flow path is controlled by alluvial sediments that have high permeability value.

\section{Materials and methods}

A comprehensive water quality monitoring study was conducted, and samples were collected from sixteen (two from geothermal fluid and fourteen from cold groundwater) monitoring stations that characterize the relation between geothermal fluid and cold groundwater resources. The research was conducted in two phases: the first phase of the study focused on the monitoring of geothermal fluid intrusion after the blowout accident into the groundwater resources around the study area. Two geothermal fluid samples (one taken from blowout geothermal fluid and the other from the KML-2 geothermal well) were collected to determine the chemistry of fluid. In addition, three geothermal monitoring wells were sampled around blowout well from 2012 to 2014 in wet and dry seasons 


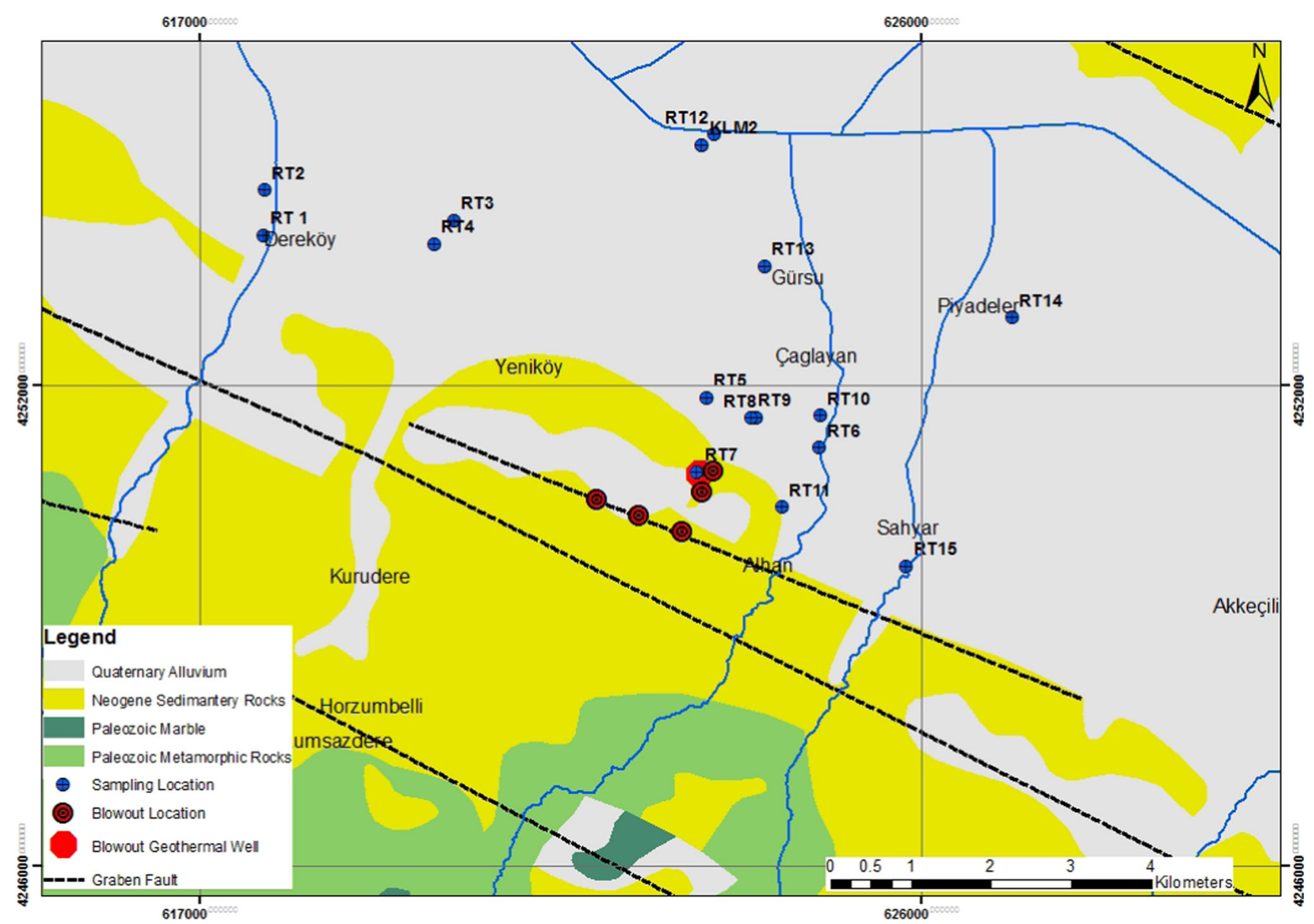

Fig. 4 Location map of the eruption and monitoring wells

(Fig. 4). The second phase of the study is focused on the cold groundwater characteristics in Alasehir Plain. A total of fourteen cold groundwater sampling points were selected among the drilling data to represent the conditions of groundwater in wet season of 2014. The two sets of samples were collected from each sampling point, one for determination of anions-cations and another for heavy metals. Samples were stored in pre-cleaned polyethylene bottles for laboratory analysis, whereas temperature, $\mathrm{pH}$ and electrical conductivity were determined in situ. Chemical analyses were performed as quickly as possible in the laboratory. If immediate analysis was not possible, samples were stored at $4{ }^{\circ} \mathrm{C}$ in the dark. The major chemical constituents were determined using standard methods described in AWWA (1995). Carbonate $\left(\mathrm{CO}_{3}{ }^{-}\right)$, bicarbonate $\left(\mathrm{HCO}_{3}{ }^{-}\right)$and chloride $\left(\mathrm{Cl}^{-}\right)$ions were determined at Laboratory of Dokuz Eylül University with neutralization and precipitation titrations using ASTM D1067 and ASTM 512-12, respectively. Precipitation titrations were based upon reactions that yield ionic compounds of limited solubility. The most important precipitating reagent was silver nitrate. Titrimetric methods based upon silver nitrate are sometimes termed argent metric methods for chloride. ASTM D516-16 gravimetric method was applied for the determination of sulfate $\left(\mathrm{SO}_{4}{ }^{2-}\right)$. Major cations $\left(\mathrm{K}^{+}, \mathrm{Na}^{+}, \mathrm{Ca}^{2+}, \mathrm{Mg}^{2+}\right)$ and heavy metals $(\mathrm{Cu}, \mathrm{Cr}, \mathrm{Cd}, \mathrm{Pb}, \mathrm{Zn}, \mathrm{B}, \mathrm{Si})$ were determined by inductively coupled plasma-mass spectroscopy (ICP-MS) at the laboratories of General Director of Water Resources, Izmir, Turkey, and ACME Laboratories (Canada). The ICP-MS instrument measures most of the elements in the periodic table. The elements can be analyzed with detection limits at or below the part per trillion (ppt). In addition, CTD divers-type data loggers that measure and store electrical conductivity, water level and temperature as a function of time were placed in a cold groundwater well (RT8), which was near the blowout geothermal well. Data were collected at every hour from 2014 to 2015 in this data logger. CTD data logger has very sensitive accuracy such that the water level, temperature and electrical conductivity accuracies were $\pm 0.5 \mathrm{~cm} \quad \mathrm{H}_{2} \mathrm{O}, \quad \pm 0.1{ }^{\circ} \mathrm{C}, \quad \pm 1 \%$ reading $\mathrm{mS} / \mathrm{cm}$, respectively. 


\section{Results and discussion}

\section{Blowout well construction plan}

One of the energy companies operating in the area planned to drill within the geothermal reservoir in Alasehir Graben (Fig. 4). In the first stage of drilling, the geothermal well was drilled up to $200 \mathrm{~m}$ in the alluvial unit which mostly contained gravel and sandy material. At this stage, a steel casing was installed and cemented to stabilize the well within the alluvial layer. After casing operation, the underlying Neogene formation, consisted of gravel, sand, claystone and sandstone, was drilled from 200 to $1000 \mathrm{~m}$. When drilling string entered the metamorphic rocks at about $1000 \mathrm{~m}$ depth, hot drilling mud and gas blowout through the well annulus. It was considered that the drilling string cut the reservoir rocks, and the high-pressure geothermal fluid entered the well due to high formation pressure and surface out along the well hole from the bottom to surface. As the well head preventer system was closed during the blowout, high-pressure fluid surface out along several fault zones cutting weakly cemented Neogene formation. A big blowout occurred on May 18, 2012, around the well, and big portion of geothermal fluid recharged back to the sediment rocks. Hot mud and pieces of small rocks were scattered on the agriculture fields with in about 200 ha area (Fig. 4). The schematic of blowout well $\log$ and well construction plan is given in Fig. 5. It was concluded that the faulty casing operation and permeable fault zone were responsible for the blowout of the geothermal fluid (Fig. 6). It was later determined that the Neogene formation should have been completely isolated by a well casing to protect the blowout in such a highly altered sedimentary layer. In order to solve the blowout problem around the well, a new geothermal well was operated at a site located near the blowout accident well in 2013. When the geothermal fluid was produced in new production well, amount of flowing blowout fluid was reduced from the accident well. In the middle of the August in 2014 , a power generation plant was established at this site and began geothermal fluid production and reinjection application.

\section{Hydrogeochemistry of geothermal fluid}

The quality of groundwater resources is a function of a number of factors such as discharge of geothermal fluid that are effective in the study area. The results of the physical and chemical analyses of the geothermal fluid derived from the blowout well are presented in Tables 1 and 2. To compare the geothermal fluid chemistry, two points were monitored: (1) the blowout well (RT7) and (2)

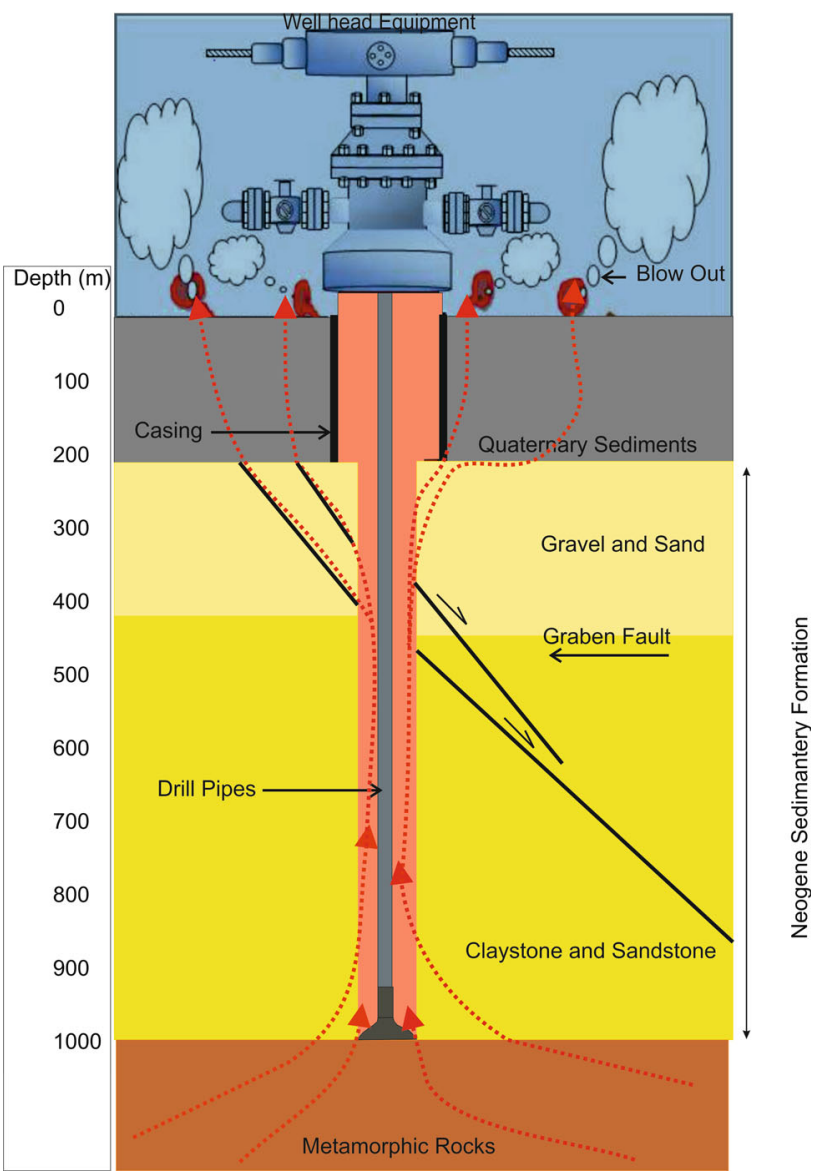

Fig. 5 Blowout geothermal well profile (modified from Toka et al. 2012)

the geothermal well (KLM-2) that was drilled near the blowout well in Alasehir Plain. KLM-2 geothermal well produced fluid from the same reservoir rock, and the Neogene formation was completely isolated with a well casing. The depth of KML-2 is $2500 \mathrm{~m}$, and this well reflected the geothermal reservoir fluid chemistry in the study area.

The surface temperature of blowout fluid (RT7) and KLM-2 geothermal well was around $85{ }^{\circ} \mathrm{C}$ and higher than $100{ }^{\circ} \mathrm{C}$, respectively, representing a possible mixture with cold groundwater. The $\mathrm{pH}$ values of geothermal fluid ranged from 8.37 to 8.72 , and these results indicated that the $\mathrm{pH}$ value of blowout water changed seasonally. The electrical conductivity of KLM-2 fluid was $3640 \mu \mathrm{S} / \mathrm{cm}$ (see Table 1); on the other hand, the electrical conductivity of blowout fluid ranged from 1842 to $2889 \mu \mathrm{S} / \mathrm{cm}$ in four sampling seasons, which demonstrated that the characteristics of flowing fluid were highly variable depending on the extent of the mixing progress.

On the basis of major ion chemistry, the Piper diagrams of study area are drawn and shown in Fig. 7. According to the Piper diagram, water samples demonstrated distinct 

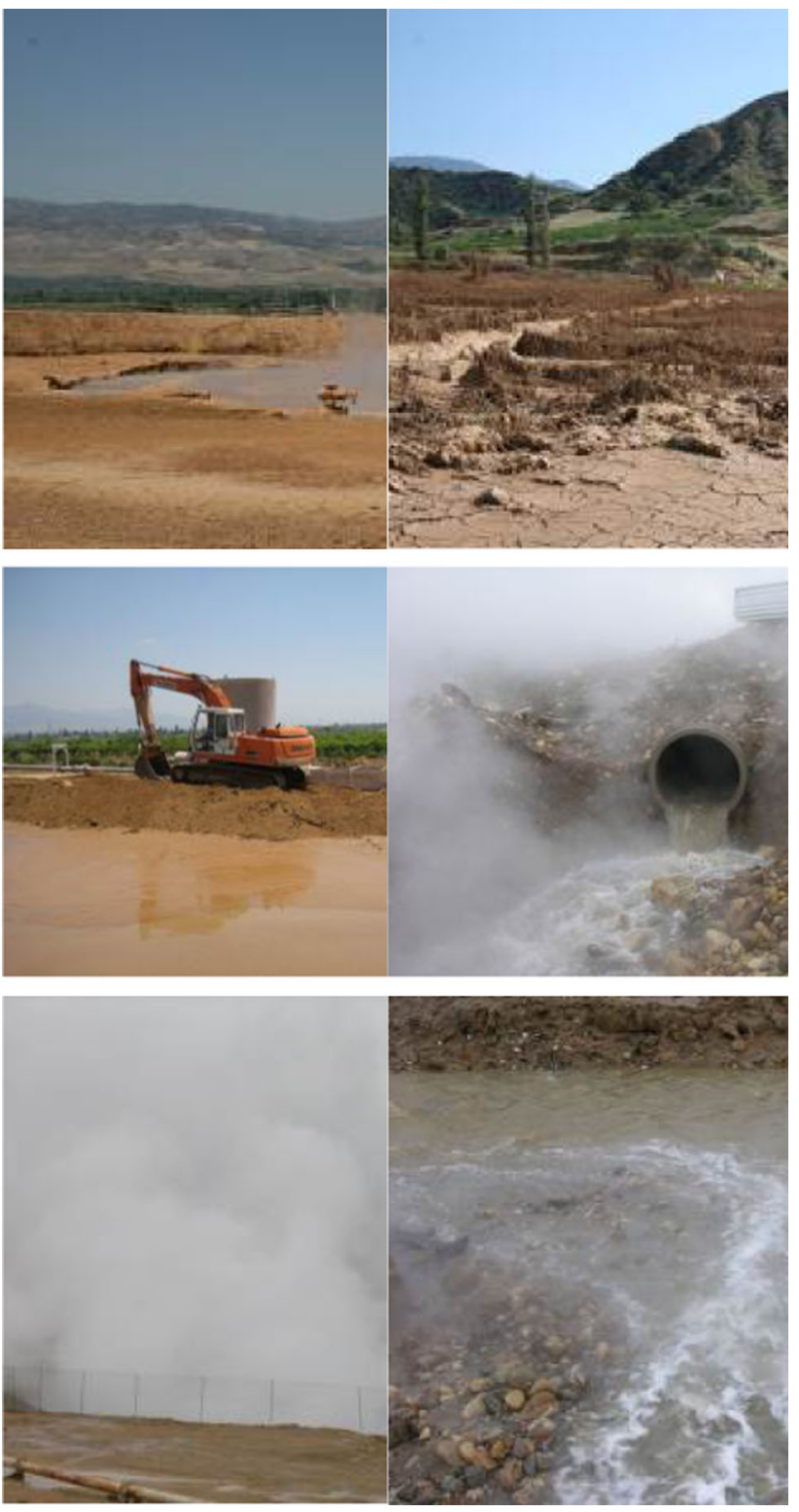

Fig. 6 Some photographs related to the geothermal blowout area (taken from Baba and Murathan 2012)

characteristics of geothermal fluid, which were rich in sodium and bicarbonate ions and were associated with metamorphic and Neogene sediments. This geothermal fluid of KLM-2 was of $\mathrm{Na}-\mathrm{HCO}_{3}$ water type. Fluid from the blowout well was dark brown and of $\mathrm{Na}-\mathrm{HCO}_{3}$ water type (Fig. 7). The reservoir rock chemistry was presumed to control the major ions of hot waters. $\mathrm{Na}^{+}$and $\mathrm{K}^{+}$concentrations in geothermal fluid were very high compared the cold groundwater. For example, the concentration of $\mathrm{Na}^{+}$ranged from 601.85 to $751.51 \mathrm{mg} / \mathrm{L}$ and the highest $\mathrm{Na}^{+}$were observed in September 2012. The blowout geothermal fluid's major ions were lower than the KLM-2 geothermal fluid due to the mixing with cold groundwater.
$\mathrm{Na}^{+}$concentration of KLM-2 geothermal fluid was $1006 \mathrm{mg} / \mathrm{L}$ which was higher than blowout geothermal fluid. The results of elemental analyses indicated the presence of hazardous and trace elements in geothermal fluids. In particular, arsenic and boron were the most important toxic elements found in the geothermal fluid. Previous studies from the Gediz Graben indicated that boron in geothermal waters reached as high as $65 \mathrm{mg} / \mathrm{L}$ (Aksoy et al. 2009; Baba and Ármannsson 2006). Similarly, extremely toxic levels of arsenic and boron were detected in the geothermal fluid in Alasehir Plain in this study. In particular, boron concentration ranged from 35.6 to $127.6 \mathrm{mg} / \mathrm{L}$ in KLM-2 geothermal water. Boron concentration in geothermal fluid was extremely higher than the national and international drinking water standards. Generally, B concentrations are high in thermal waters of western Turkey. This is related to volcanic and sedimentary rocks, but may also be controlled by the degassing of magma intrusive (Baba and Ármannsson 2006). In addition, arsenic concentration ranged from 67 to $1249 \mu \mathrm{g} / \mathrm{L}$ in the blowout geothermal fluid and reached to $3000 \mu \mathrm{g} / \mathrm{L}$ in KLM-2 geothermal well. These results indicated that arsenic was extremely higher than the national and international drinking water quality standard limit of $10 \mu \mathrm{g} / \mathrm{L}$, and this level of arsenic was a big problem for water resources and human health. Groundwater resources have been used extensively for drinking and irrigation purposes in this region. Therefore, mixing of geothermal fluid with cold water resources of the plain demonstrated a significant health risk for the inhabitants of the study area. Many parts of the study area are likely to have arsenic-containing geological formations such as altered metamorphic rocks within which geothermal resources are also expected to contain high arsenic levels. Most of these rocks are altered and fractured due to active tectonics (Baba and Sözbilir 2012).

\section{General hydrogeochemistry of groundwater}

Fourteen groundwater samples were collected in alluvial aquifer zone in 2014 to determine the general characteristics of groundwater around the study area. The results of groundwater samples are presented in Tables 1 and 2. The result shows that the temperature of the regional groundwater was directly affected from the geothermal fluid. The average temperature of groundwater is $22.7^{\circ} \mathrm{C}$ in the study area with a range of $17.1-29.5^{\circ} \mathrm{C}$, which clearly showed that it was thermally polluted. In particular, high thermal pollution can be seen in the vicinity of the blowout area, particularly around RT8 sampling point. When the temperature of water is above $25{ }^{\circ} \mathrm{C}$, it is considered to be a heated resource and is not suitable for drinking purposes according to Turkish drinking water standards. 


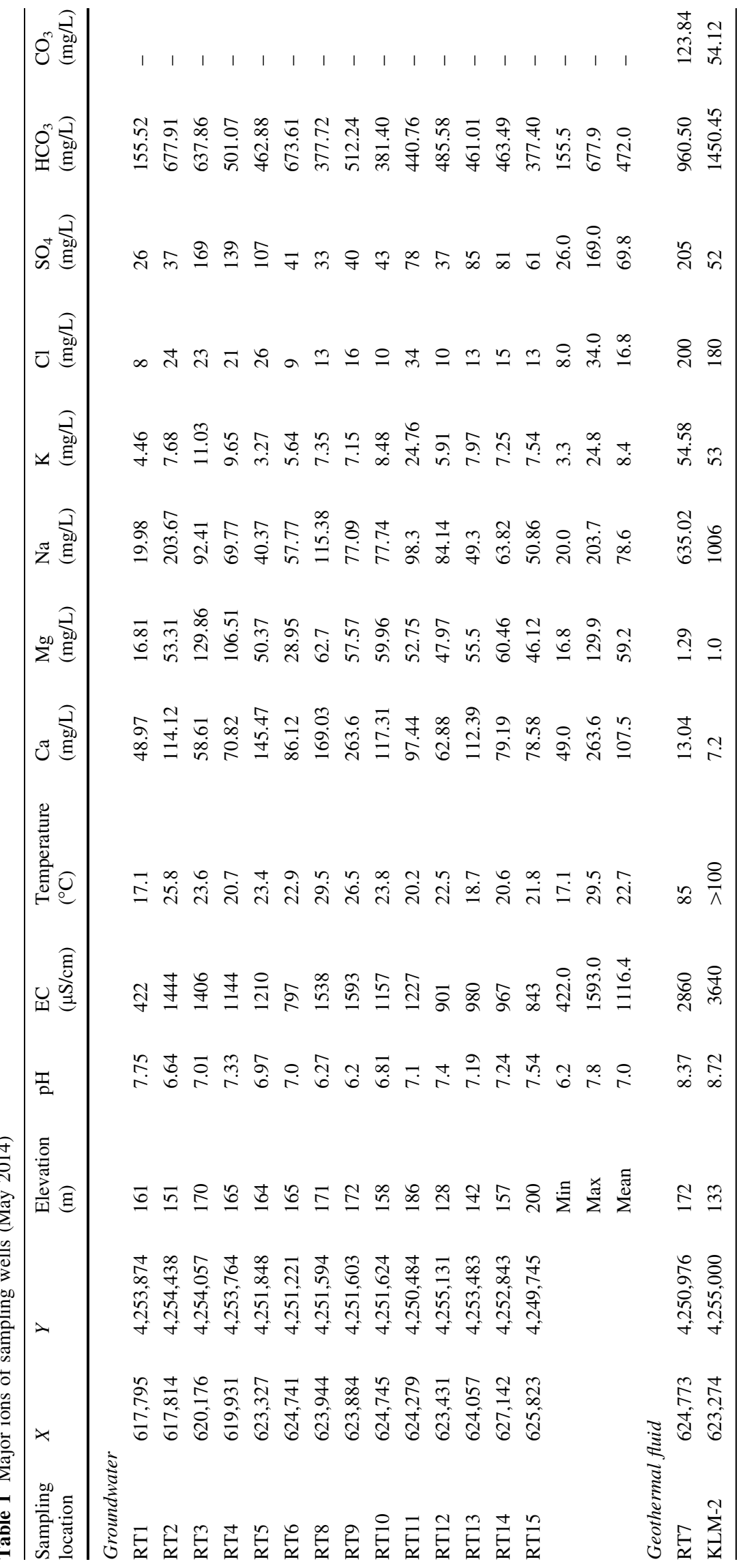


Table 2 Trace elements of sampling wells (May 2014)

\begin{tabular}{|c|c|c|c|c|c|c|c|c|c|c|c|c|}
\hline Sampling location & $\begin{array}{l}\mathrm{Al} \\
(\mathrm{mg} / \mathrm{L})\end{array}$ & $\begin{array}{l}\text { As } \\
(\mathrm{mg} / \mathrm{L})\end{array}$ & $\begin{array}{l}\text { B } \\
(\mathrm{mg} / \mathrm{L})\end{array}$ & $\begin{array}{l}\mathrm{Cu} \\
(\mathrm{mg} / \mathrm{L})\end{array}$ & $\begin{array}{l}\mathrm{Fe} \\
(\mathrm{mg} / \mathrm{L})\end{array}$ & $\begin{array}{l}\mathrm{Mn} \\
(\mathrm{mg} / \mathrm{L})\end{array}$ & $\begin{array}{l}\text { Mo } \\
(\mathrm{mg} / \mathrm{L})\end{array}$ & $\begin{array}{l}\mathrm{Ni} \\
(\mathrm{mg} / \mathrm{L})\end{array}$ & $\begin{array}{l}\mathrm{Pb} \\
(\mathrm{mg} / \mathrm{L})\end{array}$ & $\begin{array}{l}\mathrm{Li} \\
(\mathrm{mg} / \mathrm{L})\end{array}$ & $\begin{array}{l}\mathrm{Se} \\
(\mathrm{mg} / \mathrm{L})\end{array}$ & $\begin{array}{l}\mathrm{Zn} \\
(\mathrm{mg} / \mathrm{L})\end{array}$ \\
\hline RT1 & 0.007 & 0.0061 & 0.198 & 0.2577 & 0.057 & 0.00154 & 0.0007 & 0.0028 & 0.0095 & 0.0092 & 0.0003 & 0.0954 \\
\hline RT2 & 0.002 & 0.0023 & 3.713 & 0.0033 & $<0.01$ & 1.27121 & 0.001 & 0.0026 & 0.0002 & 0.1065 & 0.0008 & 0.0108 \\
\hline RT3 & 0.023 & 0.001 & 1.767 & 0.0017 & 0.012 & 0.52455 & 0.0027 & 0.0017 & 0.0003 & 0.1618 & 0.0021 & 0.0049 \\
\hline RT4 & 0.404 & 0.0017 & 1.336 & 0.0036 & 0.594 & 0.23945 & 0.0006 & 0.0026 & 0.0014 & 0.1157 & 0.003 & 0.0079 \\
\hline RT5 & 0.004 & 0.0009 & 0.864 & 0.0017 & $<0.01$ & 0.73054 & 0.0008 & 0.001 & 0.0006 & 0.0362 & 0.0017 & 0.0021 \\
\hline RT6 & 0.014 & 0.0006 & 1.26 & 0.0033 & $<0.01$ & 0.00252 & 0.0012 & 0.001 & 0.0007 & 0.0739 & 0.0006 & 0.0061 \\
\hline RT8 & 0.002 & 0.0008 & 2.964 & 0.0009 & $<0.01$ & 0.15575 & 0.001 & 0.001 & 0.001 & 0.1407 & 0.0003 & 0.0011 \\
\hline RT9 & 0.023 & 0.178 & 1.74 & 0.0054 & 1.464 & 0.23658 & 0.0003 & 0.003 & 0.0013 & 0.0958 & 0.0003 & 0.0255 \\
\hline RT10 & 0.131 & 0.0005 & 2.133 & 0.0018 & 0.196 & 0.02613 & 0.001 & 0.0009 & 0.0006 & 0.0843 & 0.0003 & 0.0239 \\
\hline RT11 & 0.06 & 0.0016 & 4.341 & 0.0034 & 0.543 & 0.01831 & 0.0005 & 0.0003 & 0.0007 & 0.1915 & 0.0016 & 0.0231 \\
\hline RT12 & 0.028 & 0.0217 & 1.594 & 0.0027 & 0.383 & 0.19942 & 0.0026 & 0.0011 & 0.0006 & 0.0626 & 0.0003 & 0.0069 \\
\hline RT13 & 0.016 & 0.0017 & 1.486 & 0.0034 & 0.097 & 0.01406 & 0.0006 & 0.001 & 0.0009 & 0.0644 & 0.0003 & 0.0045 \\
\hline RT14 & 0.001 & 0.0013 & 0.404 & 0.0016 & $<0.01$ & 0.08898 & 0.0022 & 0.0242 & 0.001 & 0.0115 & 0.0003 & 0.0052 \\
\hline RT15 & 0.005 & 0.0006 & 0.869 & 0.0078 & $<0.01$ & 0.00062 & 0.0004 & 0.0004 & 0.001 & 0.0307 & 0.0007 & 0.0202 \\
\hline Min & 0.0010 & 0.0005 & 0.1980 & 0.0009 & 0.0120 & 0.0006 & 0.0003 & 0.0003 & 0.0002 & 0.0092 & 0.0003 & 0.0011 \\
\hline Max & 0.4040 & 0.1780 & 4.3410 & 0.2577 & 1.4640 & 1.2712 & 0.0027 & 0.0242 & 0.0095 & 0.1915 & 0.0030 & 0.0954 \\
\hline Mean & 0.0514 & 0.0156 & 1.7621 & 0.0213 & 0.4183 & 0.2507 & 0.0011 & 0.0031 & 0.0014 & 0.0846 & 0.0009 & 0.0170 \\
\hline ITHASY (2005) & 0.2 & 0.001 & 1.00 & 2.0 & 0.2 & 0.05 & & & 0.001 & & 0.001 & \\
\hline \multicolumn{13}{|l|}{ Geothermal fluid } \\
\hline RT7 & 0.165 & 1.249 & 118.856 & 0.0025 & 1.212 & 0.01285 & 0.0284 & 0.0024 & 0.0004 & 5.9673 & 0.0037 & 0.0043 \\
\hline KLM-2 & 0.60 & 3.000 & 127.62 & 0.08 & 10.00 & 0.05 & 0.30 & 0.30 & 4.00 & 6.29 & 0.0003 & 0.30 \\
\hline
\end{tabular}

Fig. 7 Piper diagram of May 2014 sampling waters

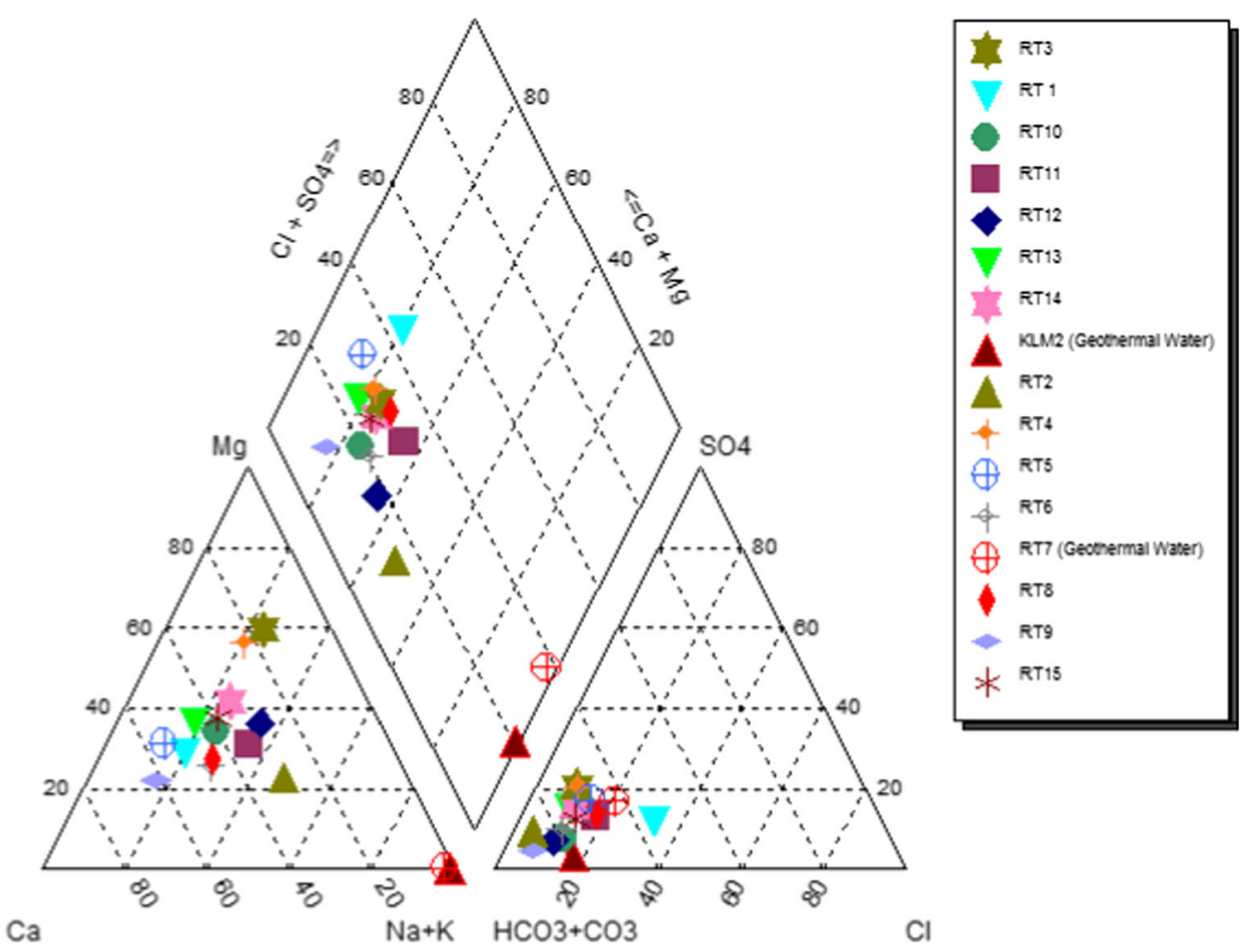

The $\mathrm{pH}$ of geothermal fluid ranged from 8.37 to 8.72 , whereas $\mathrm{pH}$ values of groundwater ranged from 6.20 to 7.75 with a mean value of 7.00 . These result indicated that geothermal fluid is alkaline. Electrical conductivity (EC) values of groundwater ranged from 422 to $1593 \mu \mathrm{S} / \mathrm{cm}$ in the plain. But EC is increasing in some groundwater wells 
(RT8 and RT9) which are close to the blowout area. The highest concentration of EC $(1593 \mu \mathrm{S} / \mathrm{cm})$ was measured in RT9 well. EC values are a good indicator for the effect of geothermal fluid on groundwater resources.

Hydrogeochemical results showed that groundwater had high $\mathrm{Ca}^{2+}$ and $\mathrm{HCO}_{3}{ }^{-}$ions. According to the Piper diagrams, groundwater was characterized as $\mathrm{Ca}-\mathrm{HCO}_{3}$ type (Fig. 7). Results also showed that the source of this water is carbonate rocks. Near the blowout site, hydrogeochemical properties of water change. Concentrations of some ions increased. The relative levels of these ions were associated with the geothermal fluid that was influential on the quality of groundwater. The sodium values of samples ranged from 20 to $203.7 \mathrm{mg} / \mathrm{L}$ with an average of $78.6 \mathrm{mg} / \mathrm{L}$ (Table 1). Calcium values of samples ranged from 49 to $263.6 \mathrm{mg} / \mathrm{L}$, magnesium values of samples ranged from 16.3 to $129.86 \mathrm{mg} / \mathrm{L}$ and potassium values ranged from 3.0 to $24.8 \mathrm{mg} / \mathrm{L}$. The highest $\mathrm{Na}^{+}$concentration was measured in RT8 sampling point. On the other hand, $\mathrm{Cl}^{-}$and $\mathrm{SO}_{4}{ }^{2-}$ concentrations in groundwater ranged from 8.0 to $34 \mathrm{mg} / \mathrm{L}$ and from 26 to $169 \mathrm{mg} / \mathrm{L}$, respectively. The concentration of the most major anions was below the contamination level set by the drinking water legislation except $\mathrm{K}^{+}$. The concentrations of ions in geothermal fluid are more than the concentration of cold groundwater. This is a normal situation due to extended rock-water interaction. The results showed that ion concentrations in cold groundwater increased near geothermal fluid site. This could be problematic for groundwater resources in the near future.

The results of some trace elements analyses are given in Table 2. Chemical results showed that the geothermal fluid contained high toxic elements compared to international and national water quality standards (WHO 2004; ITHASY 2005). The concentrations of heavy metals in geothermal fluid were higher than local cold groundwater in the study area. In particular, boron and lithium values have exceeded national and international limits. The boron limit in Turkish standards was set at $1 \mathrm{mg} / \mathrm{L}$ for drinking waters (ITASHY 2005). Similarly, boron concentrations of $1.0 \mathrm{mg} / \mathrm{L}$ or less are considered to be suitable for irrigation purposes for sensitive crops. In the geothermal fluids of the study area, boron levels reached up to $127 \mathrm{mg} / \mathrm{L}$ that was the highest boron level recorded in the entire Gediz Plain. On the other hand, boron values in local cold groundwater ranged from 0.19 to $4.34 \mathrm{mg} / \mathrm{L}$ (Table 2 ). The spatial distribution of boron concentration in the shallow aquifer is presented in Fig. 8. It can be seen from the figure that high

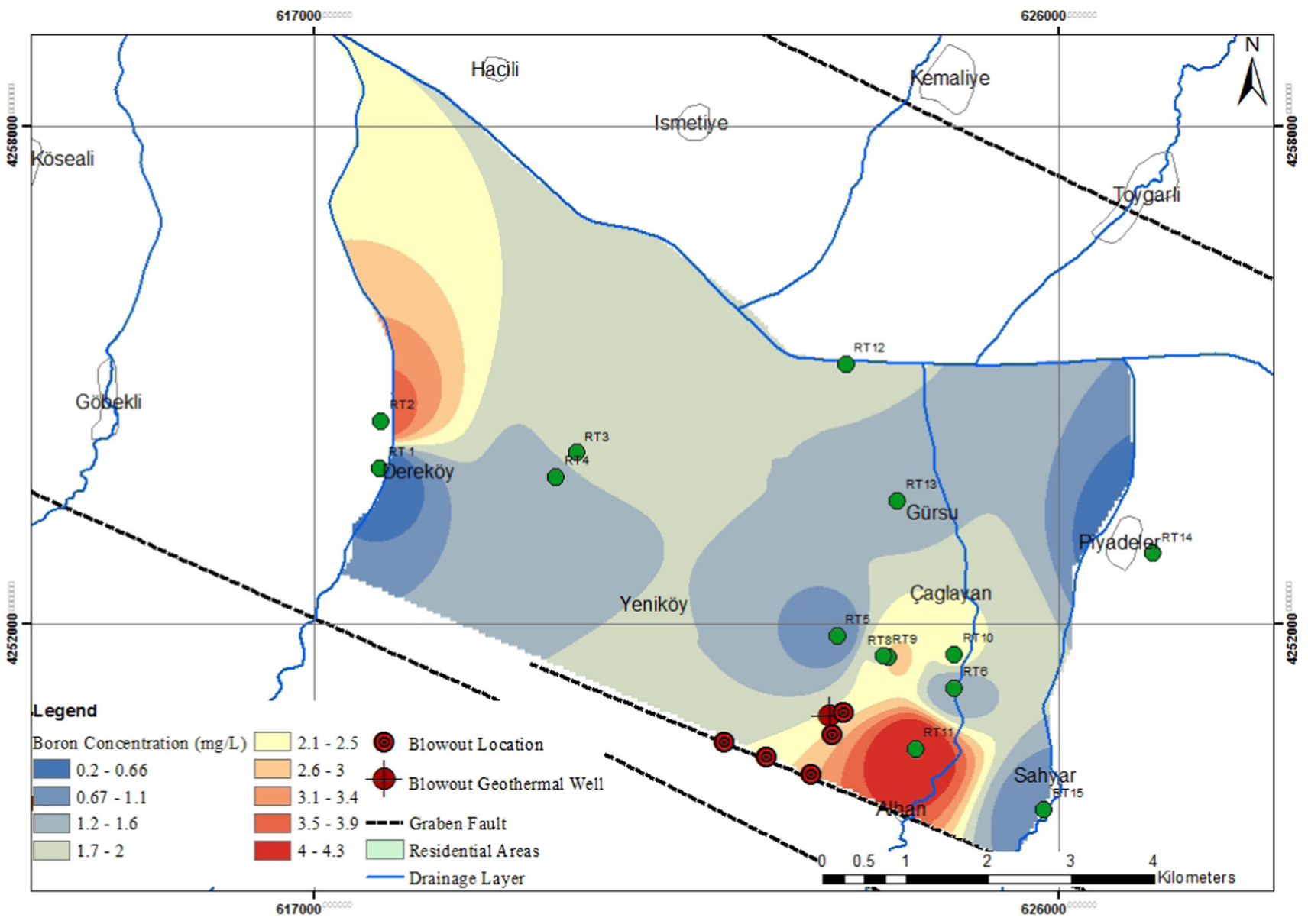

Fig. 8 Boron concentration in shallow alluvial aquifer 


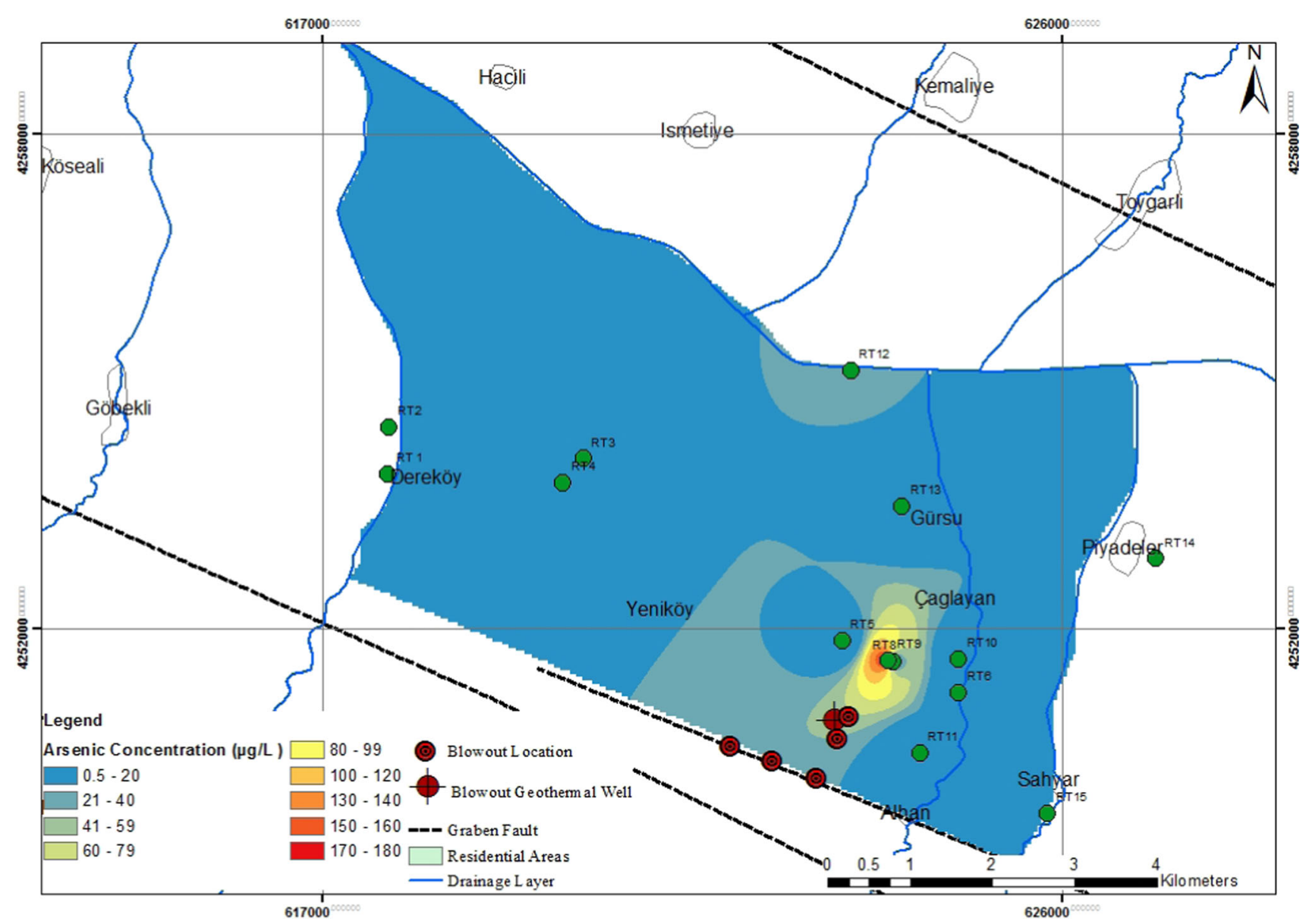

Fig. 9 Arsenic concentration in shallow alluvial aquifer

boron concentrations were observed in RT2 and RT11 monitoring wells. High boron concentration was observed near Alhan village and the eastern parts of Derekoy village where high boron is related to the geothermal fluid intrusion to the shallow alluvial aquifer (see Fig. 3). In particular, temperature of RT2 is $25.8{ }^{\circ} \mathrm{C}$ which was attributed to the effects from a nearby abandoned geothermal well. In addition, it is important note that the extremely high level of boron was determined in Alasehir Plain in deep geothermal wells. Based on the first sampling results, the groundwater chemistry was found to deteriorate near the blowout site. Mixing of geothermal fluid with cold groundwater can increase the toxic elements concentration in groundwater.

The other toxic element arsenic was also detected above the national and international water standards. When the arsenic drinking water standard level of $0.01 \mathrm{mg} / \mathrm{L}$ was considered, it was seen that the geothermal waters contained 30 times higher than this standard level. Arsenic concentrations ranged from 0.0005 to $0.178 \mathrm{mg} / \mathrm{L}$ in groundwater. High arsenic levels were observed in RT9 and RT6 monitoring wells in different seasons. Based on the 2014 general sampling analyses results, the spatial distribution of arsenic concentration in the shallow aquifer is presented in Fig. 9. Figure 9 shows that high arsenic concentrations were also observed at east of the blowout site. Spatial distribution of arsenic and boron concentration in groundwater demonstrated that the contamination from the geothermal fluid concentrated on the blowout site and near geothermal wells.

The other elements such as $\mathrm{Cu}, \mathrm{Pb}, \mathrm{Se}$ and $\mathrm{Zn}$ did not exceed the national and international limits except $\mathrm{Al}, \mathrm{Fe}$ and $\mathrm{Mn}$ concentration in groundwater. However, the concentration of $\mathrm{Al}$ and $\mathrm{Fe}$ was quite high in the geothermal fluid. The concentration of $\mathrm{Fe}$ in geothermal fluid ranged from 1.2 to $10 \mathrm{mg} / \mathrm{L}$ (Table 1). This level of $\mathrm{Fe}$ in geothermal fluid is very normal as $\mathrm{Fe}$ is known to be the second most abundant metal in earth crust. However, Fe and $\mathrm{Mn}$ in groundwater had high levels based on the national and international standards. Aluminum only exceeded the standard level at RT4 sampling point located northeast of the study area.

To understand the major ion resource in hydrochemical process, correlation analyses were carried out for $\mathrm{pH}, \mathrm{EC}$, 
Table 3 Correlation matrix for some elements (for 15 samples)

\begin{tabular}{|c|c|c|c|c|c|c|c|c|c|c|}
\hline & $\mathrm{pH}$ & EC & $\mathrm{Ca}^{2+}$ & $\mathrm{Na}^{+}$ & $\mathrm{Mg}^{2+}$ & $\mathrm{K}^{+}$ & $\mathrm{Cl}^{-}$ & $\mathrm{SO}_{4}{ }^{2-}$ & $\mathrm{HCO}_{3}^{-}$ & $\mathrm{B}^{-}$ \\
\hline $\mathrm{pH}$ & 1 & 0.445 & -0.878 & 0.707 & -0.555 & 0.719 & 0.636 & 0.326 & 0.733 & 0.753 \\
\hline $\mathrm{EC}(\mu \mathrm{S} / \mathrm{cm})$ & & 1 & -0.227 & 0.896 & -0.342 & 0.897 & 0.729 & 0.429 & 0.823 & 0.906 \\
\hline $\mathrm{Ca}^{+}(\mathrm{mg} / \mathrm{L})$ & & & 1 & -0.498 & 0.271 & -0.531 & -0.44 & -0.365 & -0.619 & -0.527 \\
\hline $\mathrm{Na}^{+}(\mathrm{mg} / \mathrm{L})$ & & & & 1 & -0.547 & 0.929 & 0.927 & 0.223 & 0.918 & 0.973 \\
\hline $\mathrm{Mg}^{2+}(\mathrm{mg} / \mathrm{L})$ & & & & & 1 & -0.517 & -0.483 & 0.283 & -0.314 & -0.599 \\
\hline $\mathrm{K}^{+}(\mathrm{mg} / \mathrm{L})$ & & & & & & 1 & 0.764 & 0.416 & 0.861 & 0.96 \\
\hline $\mathrm{Cl}^{-}(\mathrm{mg} / \mathrm{L})$ & & & & & & & 1 & $-1.40 \mathrm{E}-02$ & 0.859 & 0.828 \\
\hline $\mathrm{SO}_{4}{ }^{2-}(\mathrm{mg} / \mathrm{L})$ & & & & & & & & 1 & 0.402 & 0.346 \\
\hline $\mathrm{HCO}_{3}^{-}(\mathrm{mg} / \mathrm{L})$ & & & & & & & & & 1 & 0.884 \\
\hline $\mathrm{B}^{-}(\mathrm{mg} / \mathrm{L})$ & & & & & & & & & & 1 \\
\hline
\end{tabular}

major ions and boron as shown in Table 3. Correlation analysis was made up with Aquachem program. Boron gave strong positive correlation with $\mathrm{Na}^{+}, \mathrm{K}^{+}$and $\mathrm{Cl}^{-}$ ions. These results indicated that boron was potentially controlled by the $\mathrm{Na}^{+}$and $\mathrm{K}^{+}$ions which came from sedimentary and metamorphic rocks in the study area. High level of $\mathrm{Na}^{+}, \mathrm{K}^{+}$and $\mathrm{HCO}_{3}{ }^{-}$in geothermal fluid indicated that the geothermal water circulates in metamorphic rocks including carbonate, halite and mica minerals.

\section{Continuous monitoring groundwater chemistry}

\section{Physical parameters}

To evaluate the impact of the geothermal fluid on the groundwater, water samples were taken from three monitoring wells located near the blowout site for monitoring purposes (from blowout year to 2014) in every wet and dry season. In addition, a CTD data logger was installed in RT8 monitoring well and was operated from 2014 to 2015. This monitoring well was located next to geothermal blowout site (Fig. 10). pH and electrical conductivity (EC) of water samples collected from RT6, RT8 and RT9 monitoring wells are presented in Table 4 . The $\mathrm{pH}$ value for nearly all the wells was slightly higher than 7.0 indicating alkaline conditions, but most of them were within the normal $\mathrm{pH}$ range of 6.5-8.5 for groundwater. EC values ranged from 797 to $2889 \mu \mathrm{S} / \mathrm{cm}$ during all sampling seasons. Higher EC was measured in RT8 and RT9 wells located near the blowout area. In general, EC increased from blowout time to 2013, after that time EC showed a partial decrease. This was possibly related to the newly opened well to reduce the blowout fluid flow, which in essence played an important role to decrease the rate of geothermal fluid dispersion in the shallow alluvial aquifer.

A CTD data logger was installed into RT9 sampling well to automatically measure the water level, electrical conductivity and water temperature at hourly intervals.
These physical parameters were recorded by the data logger since July 2014. Based on the results of physical parameters, the groundwater level was shown to increase after the August 2014. In the same time, the groundwater temperature also has also shown a similar trend to the groundwater level as shown in Fig. 10. This result could be explained by geothermal water intrusion in groundwater in the monitoring area. The other physical parameter EC showed a partially similar result with groundwater temperature and level. With respect to trend analysis, EC value had a fluctuating trend from August 2014 to January 2015 in contrast to groundwater level and temperature. This EC fluctuation could be explained by the groundwater recharge in rainy seasons and geothermal application such as production or reinjection near the monitoring well. A new electrical generation power plant was contracted near the blowout site and this plant began geothermal fluid production from the blowout well. It is believed that the sudden increase in the physical parameters of RT8 drilled in the alluvial aquifer was due to the geothermal water production and reinjection applications of this power plant.

\section{Chemical parameters}

The chemical results of three monitoring wells are presented in Table 4. Generally, major ion concentrations were variable during the sampling campaign due to the geothermal fluid mixing process. The production of geothermal fluid from the blowout site and other applications were believed to further accelerate the rate of geothermal fluid mixing into the shallow alluvial aquifer. The changes of some chemical parameters are given in Fig. 11. In particular, $\mathrm{Na}^{+}$concentrations for groundwater monitoring wells ranged from 16.6 to $189.61 \mathrm{mg} / \mathrm{L}$ and the highest value was detected as $189.61 \mathrm{mg} / \mathrm{L}$ in RT9 in September 2014 arid season. $\mathrm{K}^{+}$concentration reached up to $18.24 \mathrm{mg} / \mathrm{L}$ in $\mathrm{RT} 6 . \mathrm{Na}^{+}$and $\mathrm{K}^{+}$concentration in RT8 and RT9 monitoring wells increased until May 2013. In 

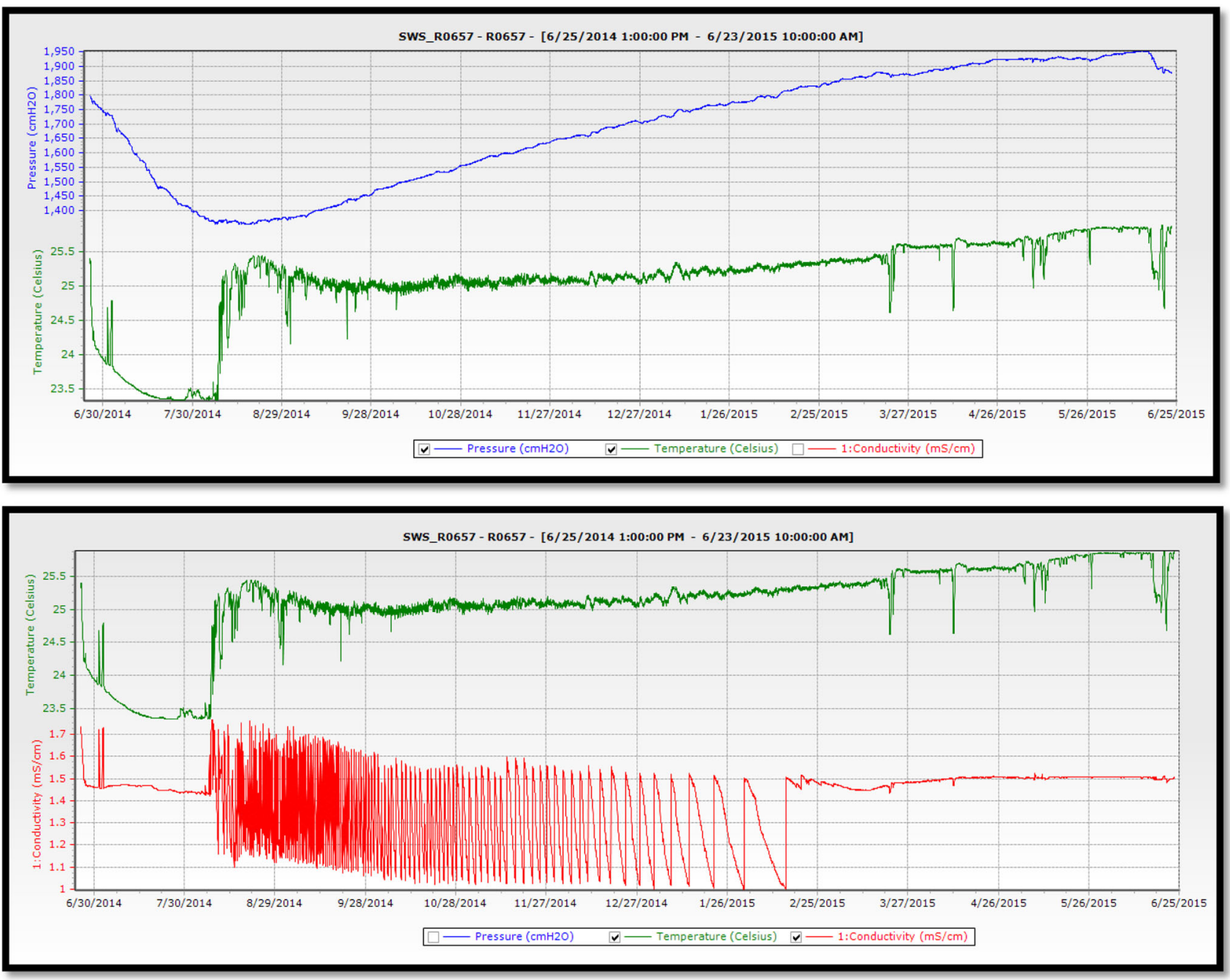

Fig. 10 Temporal changes of physical parameters in monitoring well

September 2014 for arid season, $\mathrm{Na}^{+}$and $\mathrm{K}^{+}$concentrations showed a rising trend because of the commissioning of the geothermal power plant in the middle of August 2014. In the geothermal fluid taken from the blowout site, $\mathrm{Na}^{+}$and $\mathrm{K}^{+}$concentrations ranged from 601.85 to 751.51 and from 54.58 to $4706.34 \mathrm{mg} / \mathrm{L}$, respectively. $\mathrm{Na}^{+}$and $\mathrm{K}^{+}$concentrations in geothermal fluid were extremely above $\mathrm{Na}^{+}$and $\mathrm{K}^{+}$concentrations in the groundwater as shown in Table 4.

With regard to boron and arsenic, the monitoring results indicated that arsenic concentration in groundwater changed periodically. In particular, highest arsenic level was determined to be $178 \mu \mathrm{g} / \mathrm{Lin}$ RT9 sampling point. However, boron did not yield a similar result with arsenic. Boron concentrations decreased until May 2013, but after that time showed an increasing trend again until September 2014. It can be concluded that boron concentration was mostly controlled by geothermal intrusion, which increased after August 2014 as a result of geothermal production and reinjection applications near the site.

\section{Conclusions}

According to hydrogeochemical studies and monitoring of groundwater, it could be concluded that both faulty geothermal well drilling and blowout mechanism were responsible for the geothermal fluid intrusion in alluvial aquifer system of the area. In particular, chemical and thermal pollution began to increase in the alluvial aquifer by geothermal fluid intrusion after the blowout accident. In addition, the production of geothermal fluid from the blowout well, groundwater discharge and reinjection application accelerated the dispersion of the geothermal fluid in shallow alluvial aquifer. Concentrations of several 


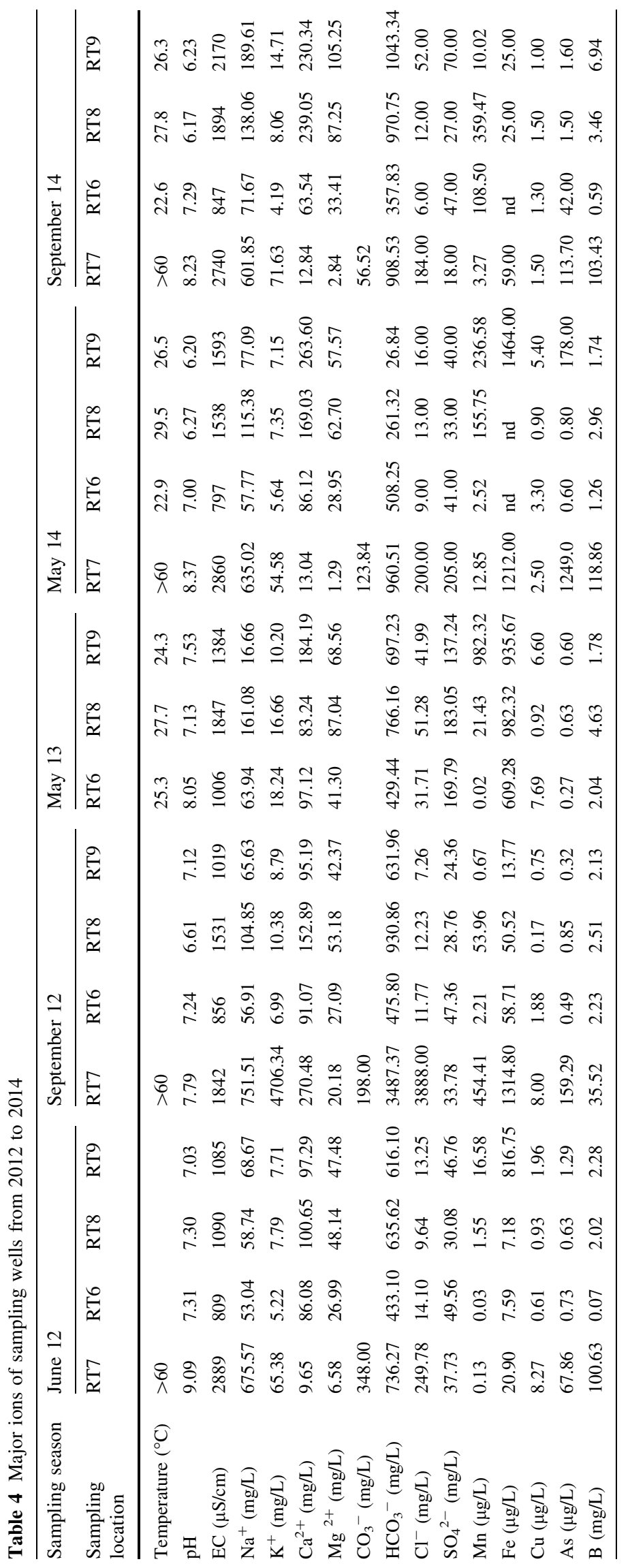



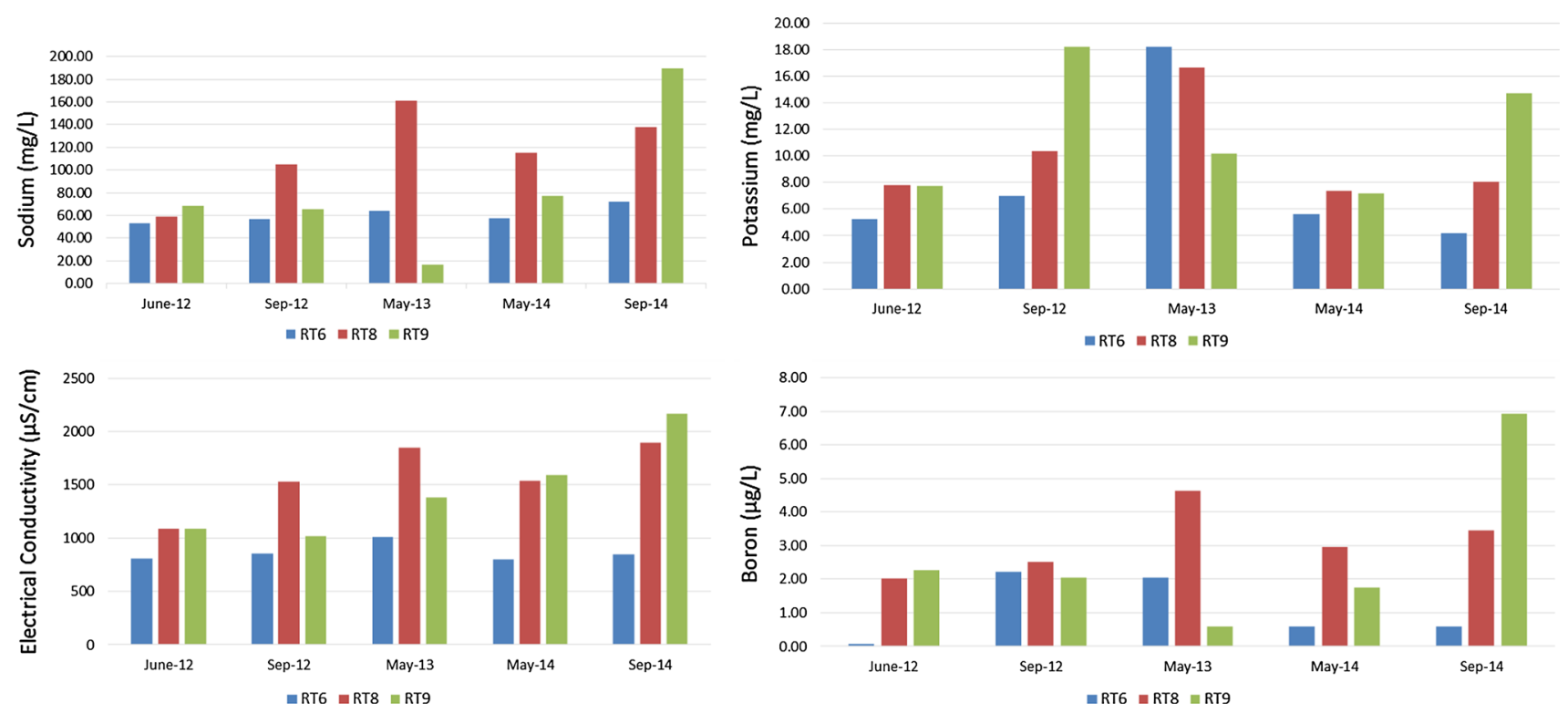

Fig. 11 Temporal changes of chemical parameters in monitoring wells

physical and chemical parameters changed in the monitoring wells based on geothermal application. In particular, physical parameters taken from data logger in RT9 and field measurement showed that the intrusion was increasing till end of this study.

Geothermal fluids generally carry a variety of toxic chemicals such as arsenic and boron. This toxic element was detected to exceed the national and international standards. Thus, blowout of geothermal fluid was also a potential source of chemical pollution for cold groundwater in region. The concentration of boron and arsenic has increased in groundwater aquifer around the study area after blowout accident.

As this aquifer was commonly used for agricultural activity, it was important to minimize the effect of geothermal fluid to the water quality of shallow alluvial aquifers. Therefore, monitoring of groundwater resources was important to assess the extent of contamination via geothermal fluids. Thus, in order to protect the groundwater in the study area that was mainly used irrigation purposes, several monitoring wells should be drilled and physically these wells should be monitored with CTD divers. It is important to note that the reinjection and geothermal drilling applications in the study area should be controlled by the State Hydraulic Works and local authorities.

Based on the results of this study, it can be considered that although geothermal waters are renewable energy sources, careful surveys and assessments should be made prior to well drilling activities particularly in agricultural areas that also depend on local groundwater reserves and in areas where groundwater is utilized for drinking purposes.
In this regard, it is important to note that geothermal wells should be planned carefully and its environmental risk should be mitigated properly for future generation water demand.

Acknowledgements This research was funded by Scientific Research Project Fund of Dokuz Eylul University through Grant No: 2014.KB.FEN.012. The authors would like to thank State Hydraulic Works for the valuable support provided during the course of the study. The authors would like to thank Dr. Orhan Gunduz for reviewing the manuscript.

\section{References}

Aksoy N, Simsek C, Gunduz O (2009) Groundwater contamination mechanism in a geothermal field: a case study of Balcova, Turkey. J Contam Hydrol 103:13-28

ASTM D1067-16 (2016) Standard test methods for acidity or alkalinity of water. American Society of the International Association for Testing and Materials (ASTM) International, West Conshohocken. www.astm.org

ASTM D512-12 (2016)Standard test methods for chloride ion in water. American Society of the International Association for Testing and Materials (ASTM) International, West Conshohocken. www.astm.org

ASTM D516-16 (2016) Standard test method for sulfate ion in water. American Society of the International Association for Testing and Materials (ASTM) International, West Conshohocken. www.astm.org

AWWA (1995) Chemical oxygen demand, argentometric method. In: Standard methods for the examination of water and wastewater, 4th Edition, no. 49. Washington, American Waste Water Association (AWWA), American Public Health Association, pp 5-12

Axtmann CR (1975) Environmental impact of a geothermal power plant. Science 187(4179):795-803

Baba A (2012) Present energy status and geothermal utilization in Turkey IAH 2012 Niagara Falls, Canada, pp 1-3 
Baba A, Ármannsson H (2006) Environmental impact of the utilization of a geothermal area in Turkey. Energy Sour $1: 267-278$

Baba A, Murathan A (2012) The influence of geothermal fluid with high heavy metals concentration on water resources, vol 66 . Geological Congress of Turkey. April 2012, Ankara, pp 124-125

Baba A, Sözbilir H (2012) Source of arsenic based on geological and hydrogeochemical properties of geothermal systems in Western Turkey. Chem Geol 334:364-377

Baba A, Gunduz O, Simsek C, Elci A, Murathan A, Sozbilir H (2016) High arsenic levels in groundwater resources of Gediz, Western Turkey. In: Arsenic research and global sustainability, AS2016 Proceedings, 19-23 June 2016, Stockholm, Sweden, pp 35-36

Bozkurt E (2001) Neotectonics of Turkey-a synthesis. Geodin Acta $14: 3-30$

Bozkurt E (2003) Origin of NE-trending basins in western Turkey. Geodin Acta 16:61-81

Demirel Z, Yildirim N (2002) Boron pollution due to geothermal wastewater discharge into the Buyuk Menderes River, Turkey. Int J Environ Pollut 18:602-608

Dogdu MS, Bayari CS (2005) Environmental impact of geothermal fluids on surface water, groundwater and streambed sediments in the Akarcay Basin, Turkey. Environ Geol 47:325-340

DSI (2014) Hydrogeological report for Gediz Plain. Turkey State Hydraulic Works, Izmir

ITHASY (2005). Regulation on waters for human consumption. Official Gazette dated 17/02/2005 No. 25730 Ankara (in Turkish)

Kocyigit A, Yusufoglu H, Bozkurt E (1999) Evidence from the Gediz graben for episodic two-stage extension in Western Turkey. J Geol Soc London 156:605-616

MTA (1980) Hot and mineral water inventory. MTA Report, Ankara

Ozen T, Bulbul A, Tarcan G (2010) Reservoir and hydrogeochemical characterizations of the salihli geothermal fields in turkey. In: Proceedings world geothermal congress 2010, Bali Indonesia 25-29 April 2010, pp 1-10
Rabet RS (2015). Investigation of geothermal waters effects on groundwater quality in Alasehir plain. MsTesis, Dokuz Eylul University, The Graduate School of Applied Science, Izmir

Seyitoglu G, Cemen İ, Tekeli O (2002) Discussion on the extensional folding in the Alasehir (Gediz) graben, western Turkey (reply). J Geol Soc 159:105-109

Simsek S (1997) Geothermal potential in northwestern Turkey. Active tectonics of Northwestern Anatolia. In: Pfister M, Schindler C (eds) The marmara poly-project. vdfhochschulverlag AG an der ETH, Zurich, pp 111-123

Simsek S (2009) Geothermal energy development Possibilities in Turkey. In: Numow conference on geothermal energy in Turkey, October, 2009 Potsdam-Germany, pp 1-6

Simsek C (2016). Investigation of geothermal waters effects on groundwater quality in Alasehir plain, Dokuz Eylul University Research Project, Project No: 2014.KB.FEN.012

Simsek S, Yildirim N, Simsek ZN, Karakus H (2002) Changes in geothermal resources at earthquake regions and their importance. In: Middle Anatolian geothermal energy and environmental symposium, pp 1-13

Sözbilir H (2002) Geometry and origin of folding in the Neogene sediments of the Gediz Graben, western Anatolia, Turkey. Geodin Acta 15:277-288

Toka B, Tugran M, Yıldız M, Durak S, Karadeniz N (2012) Technical report for geothermal eruption near Alkan Vilage in Alasehir Plain. TMMOB Chamber of Mining Engineering, Izmir

WHO (2004) World health organization. Guidelines for drinking water quality. Office of Water U.S. Environmental Protection Agency Washington DC

Yigitbas E, Elmas A, Sefinc A, Ozer N (2004) Major neotectonic features of eastern Marmara region, Turkey: development of the Adapazari-Karasu corridor and its tectonic significance. Geol J 39:179-198 